DOI 10.1590/S0104-64972015002303

\title{
Abundance and distribution of Portunidae larval phases (Crustacea: Brachyura) in the estuarine and coastal region of the Patos Lagoon, southern Brazil
}

\author{
Rony Roberto Ramos Vieira and Danilo Koetz de Calazans
}

(RRRV, DKC) Laboratório de Crustáceos Decápodos, Instituto de Oceanografia, Universidade Federal do Rio Grande. Av. Itália, km 8, Caixa Postal 474. 96201-900 Rio Grande, Rio Grande do Sul, Brazil. E-mail: (RRRV) ronycrab@gmail.com

\begin{abstract}
The abundance and distribution of larval phases of the Portunidae found in the estuary of the Patos Lagoon and the coastal region were studied during two years (1995 and 1999). A conical net $(165 \mathrm{~cm}$ long, $60 \mathrm{~cm}$ mouth, and $330 \mu \mathrm{m}$ mesh) equipped with a flowmeter was towed for three minutes at 2 knots at six stations within the estuary and four stations in the coastal region. Samplings were carried out on the surface and near the bottom. At each sampling location, the salinity and temperature were also recorded. In 1995, the zoeae of Arenaeus cribrarius (Lamarck, 1818), Callinectes sapidus Rathbun, 1896 and Achelous spinicarpus Stimpson, 1871 were caught, resulting in a total abundance of 121.98 ind. $100 \mathrm{~m}^{-3}$ (90.95 ind. $100 \mathrm{~m}^{-3}$ on the surface and 31.03 ind. $100 \mathrm{~m}^{-3}$ near the bottom). A total of 452.27 ind.100 $\mathrm{m}^{-3}$ were caught in the megalopa phase $\left(13.49\right.$ ind. $100 \mathrm{~m}^{-3}$ on the surface and 438.78 ind $100 \mathrm{~m}^{-3}$ near the bottom). In 1999, only zoeae of $C$. sapidus were caught, resulting in a total abundance of 419.78 ind. $100 \mathrm{~m}^{-3}$ (386.98 ind. $100 \mathrm{~m}^{-3}$ on the surface and 32.8 ind. $100 \mathrm{~m}^{-3}$ near the bottom). Megalopae of these three species were caught, resulting in a total abundance of 179.91 ind. $100 \mathrm{~m}^{-3}$ (25.38 ind.100 $\mathrm{m}^{-3}$ on surface and 154.53 ind $.100 \mathrm{~m}^{-3}$ near the bottom). Summer was the season with the highest abundance of larvae in both years. During spring and summer, spawning was observed in the estuarine region of the Patos Lagoon.
\end{abstract}

Key words: Achelous spinicarpus, Arenaeus cribrarius, Callinectes sapidus, crab larvae, meroplankton.

\section{INTRODUCTION}

Estuaries are important regions for many estuarine and coastal invertebrate and vertebrate species because they are used as growth and feeding areas during larval and juvenile phases. Decapod larvae are an important segment of estuarine meroplankton and their coastal regions, and they play an important role in the food chain, as they are a food resource mostly for fish larvae (Drake and Arias, 1993). The early life stages of most marine species are affected by environmental factors such as temperature, salinity and currents that transport larvae horizontally over long distances (at $\mathrm{km}$ scale) because advection exceeds the capacity of larval swimming (Archambault and Bourget, 1999; Calderon-Aguilera et al., 2003). Many estuarine invertebrates developed behavioral mechanisms that increased the retention of larvae in the estuary; others exported their larvae to coastal waters, where development occurred (Epifanio, 1988). Many species of Brachyura Linnaeus, 1758 are present in estuarine regions during their complete life cycle. However, Portunidae Rafinesque, 1815 zoeal stages are transported to the coastal adjacent areas to complete their zoeal development and return to estuarine habitat during their megalopa phase (McConaugha et al., 1983; Johnson et al., 1984; Epifanio, 1988; 1995; McConaugha, 1988; 
Epifanio et al., 1989; Goodrich et al., 1989; Little, 1990; Blanton et al., 1995; Lochmann et al., 1995).

The Patos Lagoon is located in southern Brazil between $30^{\circ} \mathrm{S}$ and $32^{\circ} \mathrm{S}$. It occupies an area of approximately $10,000 \mathrm{~km}^{2}$ and is the largest choked coastal lagoon in the world (Kjerfe, 1986). The estuarine area of the Patos Lagoon is $971 \mathrm{~km}^{2}$ and it is connected to the Atlantic Ocean in the southern portion by a single channel $20 \mathrm{~km}$ long, with a width between $0.5 \mathrm{~km}$ and $3 \mathrm{~km}$. The estuarine area, together with the coastal region, stands out among the coastal environments of the Southwest Atlantic for their ecological and social-economic importance (Asmus and Tagliani, 1998; Garcia et al., 2001). In addition, it is also an important nursery area for several invertebrate and vertebrate species. Meteorological processes, mostly wind, control the water exchange between the estuary and the continental shelf near the Patos Lagoon and are responsible for the transport of holoplanktonic and meroplanktonic species (Costa et al., 1988; Muelbert and Weiss, 1991; Abreu and Castello, 1998). Although many studies were conducted in this region (for review see Seeliger et al., 1998), few studies were performed on zooplankton (Montú, 1980; Duarte et al., 2014) and meroplankton (Rieger and D'Incao, 1991; Calazans, 2002).

Several studies on the Brazilian coast have focused on the biology, ecology, larval and juvenile development, genetics, distribution and occurrence of species belonging to the genera Arenaeus Dana, 1851, Callinectes Stimpson, 1860 and Achelous De Haan, 1833: Coelho and Ramos Porto (1995); Avila and Branco (1996); Mantelatto and Fransozo (1996; 1997; 1999a; 1999b); Barros et al. (1997); Teixeira and Sá (1998); Mantelatto and Martinelli (1999); Negreiros-Fransozo et al. (1999; 2007); Sankarankutty et al. (1999); Barutot et al. (2001); Chacur and Negreiros-Fransozo (2001); Mantelatto and Christofoletti (2001); Mantelatto et al. (2002; 2009); Pinheiro and Fransozo (2002); Weber et al. (2003); Baptista-Metri et al. (2005); Oliveira et al. (2006); Bolla Júnior et al. (2008); Almeida et al. (2010); Rodrigues et al. (2011); Araújo et al. (2012); Pardal-Souza and Pinheiro (2013); Rodrigues and D'Incao (2014). However, no studies focused on the distribution and abundance of larvae.
The goal of the present study was to determine the larval abundance and distribution of Achelous spinicarpus Stimpson, 1871, Arenaeus cribrarius (Lamarck, 1818) and Callinectes sapidus Rathbun, 1896 collected on the surface and the bottom of the estuarine and coastal regions of the Patos Lagoon during 1995 and 1999.

\section{Material and Methods}

\section{Sampling design}

Daytime samples were collected in the navigation channel of the Patos Lagoon and coastal region fortnightly during 1995 and 1999. In 1995, samples were taken from five points within the estuary [Saco do Retiro (SR), São José do Norte (SJ), Pier Copesul (PC), Pier da Marinha (PA) and Entre bóias 7 and $8(\mathrm{~EB})]$ and three in the coastal region [Ponta dos Molhes (PO), Terminal Turístico (TT) and 1 Milha Leste (MI)]. In 1999, samples were taken from four points within the estuary [SJ, PC, Tecon (TC) and EB] and three in the coastal region [PO, Paralelo aos Molhes (PR) and TT] (Fig. 1).

At each point, horizontal hauls were performed at the surface and near the bottom with a conical net that was $165 \mathrm{~cm}$ long, $60 \mathrm{~cm}$ diameter and $330 \mu \mathrm{m}$ mesh with flowmeter. The net was towed for three minutes at a speed of two knots. In the bottom hauls, after three minutes, the net was closed with a manual closing device and raised. The sampled material was immediately preserved with $4 \%$ formaldehyde solution. At each sampling point, the surface and bottom temperatures and salinities were obtained with a thermosalinometer.

\section{Samples analysis}

The Portunidae larvae were separated from the other larvae in the samples under a stereoscopic microscope. A Nomarski microscope and camcorder were used to observe and identify the species. The identification followed Vieira and Calazans (2010).

For the purposes of relative seasonal abundance and distribution, the samples were grouped for summer (January, February and March), autumn (April, May and June), winter (July, August and September) and spring (October, November and December). 


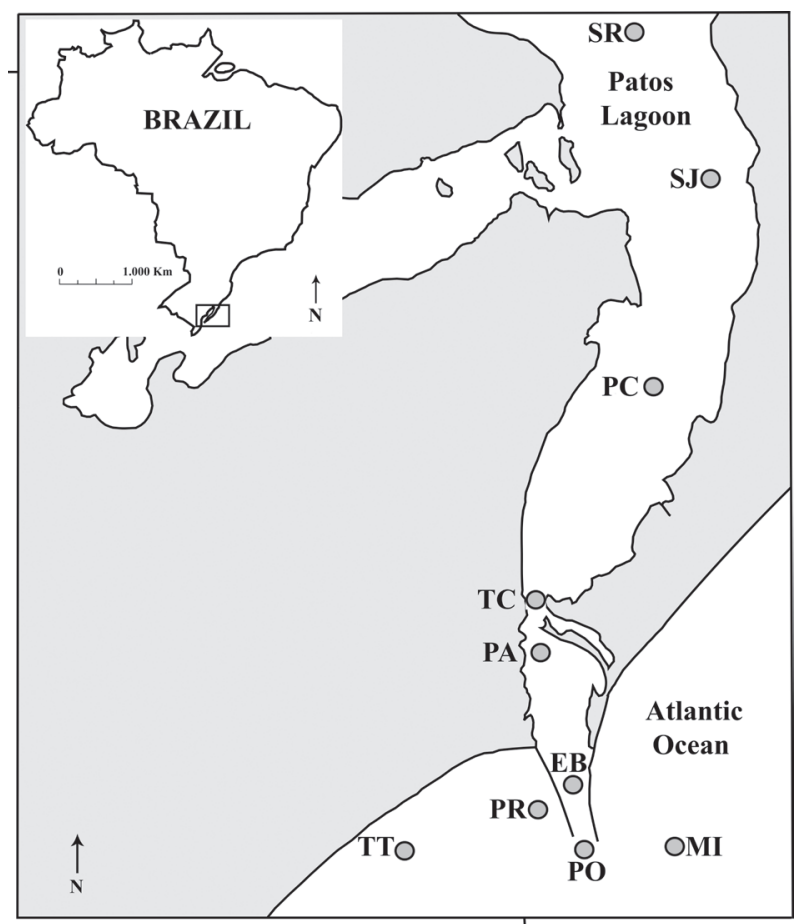

Figure 1. Positions of the sampling points within the estuary of the Patos Lagoon: Saco do Retiro (SR), São José do Norte (SJ), Pier Copesul (PC), Tecon (TC), Píer da Marinha (PA) and Entre Bóias 7 and 8 (EB). Points in the coastal region of the Patos Lagoon: Ponta dos Molhes (PO), Paralelo aos Molhes (PR), Terminal Turístico (TT) and 1 Milha Molhe Leste (MI).

Larval abundance was expressed as ind $100 \mathrm{~m}^{-3}$. For distribution, a geometric progression of base 3 was used to allow a rapid interpretation of the abundance categories contours. The abundance magnitude, established in this way, provided a scale as follows: absent [0]; 1 extremely rare ]0,1]; 2 very rare ]1,3]; 3 rare ]3,9]; 4 normal ]9,27]; 5 abundant ]27,81]; 6 very abundant ]81,243] and 7 extremely abundant 1243,729] (Nichols and Thompson, 1988).

\section{Statistical analysis}

The level of significance for tests was $a=0.05$, and the results were considered statistically significant when the $\mathrm{p}$ value was less than $0.05(\mathrm{p}<0.05)$. A non-parametric Kruskall-Wallis (Zar, 1999) analysis was used to test the larval stages abundance against the following factors: depth (surface and bottom) and seasons of the year.

The sites "EB" and "1 MI" performed in the first year and "PR" in the second year were not included in the statistical analysis because they were performed only in one season.

\section{RESULTS}

\section{Temperature and salinity}

During the two years of sampling, the surface and bottom mean temperatures were not significantly different for the same period of the year (Tab. 1). Surface temperature was slightly higher than the bottom temperature, except in autumn 1995. The seasonal variations are shown in Tab. 1 .

The average salinity during 1995 and 1999 increased towards the bottom. The seasonal variations are shown in Tab. 2. In both years, the mean salinity values were lower in the points located within estuary than in the points located in the coastal region (Figs. 2 and 3).

\section{Species composition - 1995}

All zoeae collected were in first stage. The total abundance was 121.98 ind $100 \mathrm{~m}^{-3}$ and zoeae of C. sapidus were the most abundant (97\%). For megalopae, the abundance was 452.27 ind.100 $\mathrm{m}^{-3}$ and the most abundant species was $C$. sapidus $(63 \%)$.

\section{Zoea phase}

On the surface, the total abundance of zoeae was 90.95 ind $.100 \mathrm{~m}^{-3}$ and belonged to $A$. spinicarpus and $C$. sapidus that were caught in three seasons of the year. In summer, C. sapidus was the most abundant species, with 53.97 ind $100 \mathrm{~m}^{-3}$ caught in three points within the estuary and two points in the coastal region (Fig. 4A). Achelous spinicarpus had an abundance of 4.05 ind $100 \mathrm{~m}^{-3}$ in the summer, and all of the individuals were caught in one site within the estuary (Fig. 4D). During autumn, all of the identified zoeae were $C$. sapidus caught at one site on the coastal region, and the abundance was 13.18 ind.100 $\mathrm{m}^{-3}$ (Fig. 4B). In winter, no zoeae were collected. In spring, only C. sapidus zoeae were collected in three sites within the estuary and at one site in the coastal region, and the abundance was of 19.75 ind. $100 \mathrm{~m}^{-3}$ (Fig. 4C). For zoeae caught on the surface, the summer was significantly different from the other seasons of the year for zoeae of $C$. sapidus (Tab. 3). When we analyzed the zoeae of all of the species together, we verified that the summer and spring were significantly different from the other seasons (Tab. 3). 
Table 1. Mean values of temperatures $\left({ }^{\circ} \mathrm{C}\right)$ on the surface and the bottom in the estuary and coastal region of the Patos lagoon, southern Brazil, during 1995 and 1999. MM, monthly means; SM, seasons means, \pm standard deviation.

\begin{tabular}{|c|c|c|c|c|c|c|}
\hline \multirow[t]{2}{*}{ YEARS } & \multirow[b]{2}{*}{ SEASONS } & \multicolumn{3}{|c|}{ SURFACE } & \multicolumn{2}{|c|}{ BOTTOM } \\
\hline & & $\begin{array}{c}\text { MONTHS } \\
\text { January }\end{array}$ & $\begin{array}{c}\mathrm{MM} \\
24.2 \pm 1.78\end{array}$ & SM & $\begin{array}{c}\text { MM } \\
23 \pm 4.72\end{array}$ & SM \\
\hline \multirow{11}{*}{1995} & \multirow[t]{2}{*}{ SUMMER } & February & $24.4 \pm 0.86$ & \multirow[t]{2}{*}{$23.9 \pm 1.39$} & $23.5 \pm 0.45$ & \multirow[t]{3}{*}{$23 \pm 3.17$} \\
\hline & & March & $22.7 \pm 0.62$ & & $22.6 \pm 0.51$ & \\
\hline & \multirow{4}{*}{ AUTUMN } & April & $19.1 \pm 1.10$ & \multirow{4}{*}{$16.4 \pm 2.30$} & $18.4 \pm 4.44$ & \\
\hline & & May & $16 \pm 1.22$ & & $16.1 \pm 0.39$ & \multirow{3}{*}{$20.9 \pm 2.88$} \\
\hline & & June & $14.6 \pm 1.51$ & & $14.3 \pm 1.30$ & \\
\hline & & July & $13.6 \pm 0.45$ & & $13.5 \pm 0.65$ & \\
\hline & \multirow[t]{3}{*}{ WINTER } & August & $13.8 \pm 2.15$ & \multirow[t]{3}{*}{$13.9 \pm 1.72$} & $13.4 \pm 1.90$ & \multirow[t]{3}{*}{$12.9 \pm 1.2$} \\
\hline & & September & $15.7 \pm 1.47$ & & $14.3 \pm 0.48$ & \\
\hline & & October & $18.6 \pm 1.29$ & & $18.1 \pm 1.36$ & \\
\hline & \multirow[t]{2}{*}{ SPRING } & November & $22.5 \pm 4.16$ & \multirow[t]{2}{*}{$21.5 \pm 3.54$} & $19.0 \pm 1.79$ & \multirow[t]{2}{*}{$20.9 \pm 2.47$} \\
\hline & & December & $23.0 \pm 1.86$ & & $22.5 \pm 1.68$ & \\
\hline \multirow{12}{*}{1999} & \multirow{3}{*}{ SUMMER } & January & $23.8 \pm 0$ & \multirow{3}{*}{$24.6 \pm 1.36$} & & \multirow{3}{*}{$24.1 \pm 0.8$} \\
\hline & & February & $24.6 \pm 1.02$ & & $24.1 \pm 0.57$ & \\
\hline & & March & $27.6 \pm 1.6$ & & $24.3 \pm 0.98$ & \\
\hline & \multirow{3}{*}{ AUTUMN } & April & $20.1 \pm 2.49$ & \multirow{3}{*}{$18.6 \pm 2.57$} & $20.0 \pm 2.61$ & \multirow{3}{*}{$18.5 \pm 2.6$} \\
\hline & & May & $18.6 \pm 0.39$ & & $18.5 \pm 0.22$ & \\
\hline & & June & $14.7 \pm 0.38$ & & $14.6 \pm 0.38$ & \\
\hline & \multirow{4}{*}{ WINTER } & July & $13.7 \pm 0.42$ & \multirow{4}{*}{$14 \pm 1.64$} & $13.4 \pm 0.18$ & \multirow{4}{*}{$13.3 \pm 1.03$} \\
\hline & & August & $11.5 \pm 0.37$ & & $11.3 \pm 0.17$ & \\
\hline & & September & $15.5 \pm 0.93$ & & $13.9 \pm 0.58$ & \\
\hline & & October & - & & - & \\
\hline & \multirow[t]{2}{*}{ SPRING } & November & $21.6 \pm 2.08$ & \multirow[t]{2}{*}{$22.4 \pm 1.60$} & $21 \pm 1.45$ & \multirow[t]{2}{*}{$21.8 \pm 1.29$} \\
\hline & & December & $23.3 \pm 0.48$ & & $22.6 \pm 0.19$ & \\
\hline
\end{tabular}

Table 2. Mean values of salinity on the surface and the bottom in the estuary and coastal region of the Patos lagoon, southern Brazil, during 1995 and 1999. MM, monthly means; SM, seasons means, \pm standard deviation.

\begin{tabular}{|c|c|c|c|c|c|c|}
\hline \multirow{2}{*}{ YEARS } & \multirow{3}{*}{ SEASONS } & \multicolumn{3}{|c|}{ SURFACE } & \multicolumn{2}{|c|}{ BOTTOM } \\
\hline & & MONTHS & MM & SM & MM & SM \\
\hline \multirow{13}{*}{1995} & & January & $15.1 \pm 11.67$ & \multirow{3}{*}{$18.6 \pm 14.12$} & $25.8 \pm 7.07$ & \multirow{3}{*}{$28.9 \pm 6.09$} \\
\hline & \multirow{2}{*}{ SUMMER } & February & $17.0 \pm 15.37$ & & $33 \pm 1.53$ & \\
\hline & & March & $22.4 \pm 16.01$ & & $29.8 \pm 2.53$ & \\
\hline & \multirow{4}{*}{ AUTUMN } & April & $22.8 \pm 4.42$ & \multirow{4}{*}{$18.9 \pm 7.61$} & $24.1 \pm 3.83$ & \multirow{4}{*}{$20.9 \pm 7.69$} \\
\hline & & May & $17.1 \pm 6.40$ & & $21 \pm 3.83$ & \\
\hline & & June & $16.8 \pm 8.89$ & & $18.3 \pm 8.98$ & \\
\hline & & July & $5.4 \pm 2.54$ & & $10.7 \pm 8.03$ & \\
\hline & \multirow[t]{3}{*}{ WINTER } & August & $3.7 \pm 2.94$ & \multirow[t]{2}{*}{$7.0 \pm 5.52$} & $6.6 \pm 10.45$ & \multirow[t]{2}{*}{$12.9 \pm 10.67$} \\
\hline & & September & $8.2 \pm 7.90$ & & $23.75 \pm 0.92$ & \\
\hline & & October & $16.3 \pm 9.81$ & \multirow{4}{*}{$15.2 \pm 11.80$} & $10.6 \pm 1.34$ & \multirow{4}{*}{$20.9 \pm 10.85$} \\
\hline & \multirow{3}{*}{ SPRING } & November & $13 \pm 15.48$ & & $24.3 \pm 4.40$ & \\
\hline & & December & $26.8 \pm 2.81$ & & $27.4 \pm 2.07$ & \\
\hline & & January & $28.6 \pm 2.12$ & & - & \\
\hline \multirow{11}{*}{1999} & \multirow[t]{3}{*}{ SUMMER } & February & $21.7 \pm 10.99$ & \multirow[t]{3}{*}{$20.9 \pm 11.71$} & $25.9 \pm 9.5$ & \multirow[t]{3}{*}{$27.7 \pm 10.16$} \\
\hline & & March & $22.7 \pm 13.35$ & & $29.1 \pm 10.73$ & \\
\hline & & April & $17 \pm 8.44$ & & $22.8 \pm 10.19$ & \\
\hline & \multirow[t]{3}{*}{ AUTUMN } & May & $24.3 \pm 11.81$ & \multirow[t]{3}{*}{$18.6 \pm 10.91$} & $31.9 \pm 0.09$ & \multirow[t]{3}{*}{$26.7 \pm 10.60$} \\
\hline & & June & $12.4 \pm 14.49$ & & $13.1 \pm 14.14$ & \\
\hline & & July & $7.1 \pm 8.85$ & & $20.5 \pm 9.76$ & \\
\hline & \multirow[t]{3}{*}{ WINTER } & August & $14.1 \pm 6.05$ & \multirow[t]{3}{*}{$10.3 \pm 9.63$} & $24.7 \pm 6.28$ & \multirow[t]{3}{*}{$23.1 \pm 17.66$} \\
\hline & & September & $8.1 \pm 10.77$ & & $27.7 \pm 1.15$ & \\
\hline & & October & - & & - & \\
\hline & \multirow[t]{2}{*}{ SPRING } & November & $29 \pm 4.43$ & \multirow[t]{2}{*}{$30 \pm 4.92$} & $31.6 \pm 1.21$ & \multirow[t]{2}{*}{$31.7 \pm 1.84$} \\
\hline & & December & $30.3 \pm 5.56$ & & $31.1 \pm 2.32$ & \\
\hline
\end{tabular}

In the bottom samples, the total abundance of zoeae was 31.03 ind. $100 \mathrm{~m}^{-3}$. They all belonged to $C$. sapidus and were caught during summer and spring. In summer, the abundance was 11.48 ind. $100 \mathrm{~m}^{-3}$, the zoeae were caught at two sites within the estuary and two sites in the coastal region
(Fig. 4E). In spring, the abundance was 19.55 ind. $100 \mathrm{~m}^{-3}$, and the zoeae were caught in three sites within the estuary (Fig. 4F). There was no significant difference $(\mathrm{p}>0.05)$ among seasons of the year for the zoea stage of each species caught on the bottom (Tab. 3). However, when the zoeae 


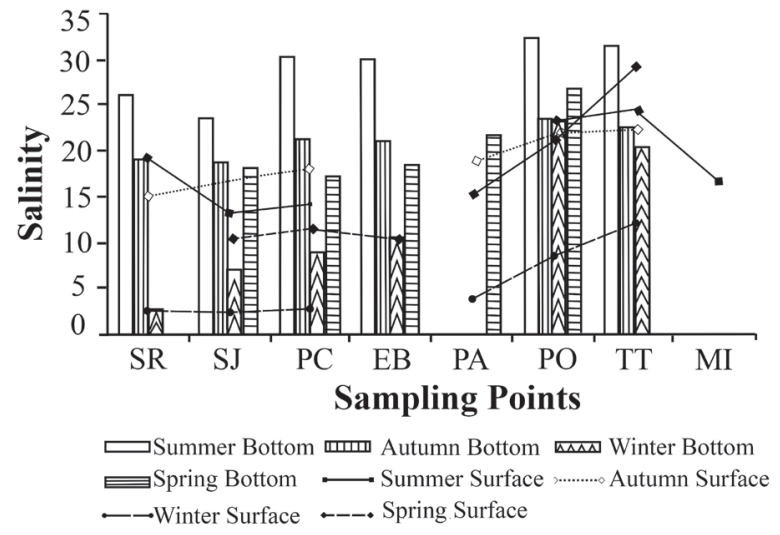

Figure 2. Mean values of salinities on the surface and the bottom at each sample point during 1995. Points within the estuary of the Patos Lagoon: Saco do Retiro (SR), São José do Norte (SJ), Pier Copesul (PC), Entre bóias 7 and 8 (EB), Pier da Marinha (PA). Points in the coastal region of the Patos Lagoon: Ponta dos Molhes (PO), Terminal Turístico (TT) and 1 Milha Leste (MI).

of all of the species were combined, the summer and spring were significantly different from the others seasons (Tab. 3).

There were no significant differences ( $p>0.05)$ between the surface and the bottom (Tab. 3) for the zoea stage of each species caught. Additionally, there was no significant difference between the surface and bottom when we analyzed all of the species together (Tab. 3).

\section{Megalopa phase}

On the surface, megalopae of $C$. sapidus and $A$. cribrarius were captured only in summer with a total abundance of 13.49 ind. $100 \mathrm{~m}^{-3}$. The most abundant species was $C$. sapidus $\left(7.71\right.$ ind $\left..100 \mathrm{~m}^{-3}\right)$, caught in one site within the estuary (PC) and one site in the coastal region (TT). The abundance of A. cribrarius was 5.78 ind. $100 \mathrm{~m}^{-3}$, and all were caught at one site within the estuary (PC). For the seasons of the year, the summer was significantly different from the other seasons (Tab. 3).

In the bottom samples, the total abundance of megalopae was 438.78 ind. $100 \mathrm{~m}^{-3}$ and belonged to all the three species, all caught during the summer. The abundance of $A$. cribrarius was 106.75 ind.100 $\mathrm{m}^{-3}$, caught in four sites within the estuary and one site in the coastal region (Fig. 5A). Callinectes sapidus was the most abundant species with 279.6 ind. $100 \mathrm{~m}^{-3}$ caught in four sites within the estuary and one site in the coastal region (Fig. 5B). The abundance of $A$. spinicarpus was 53.43 ind.100

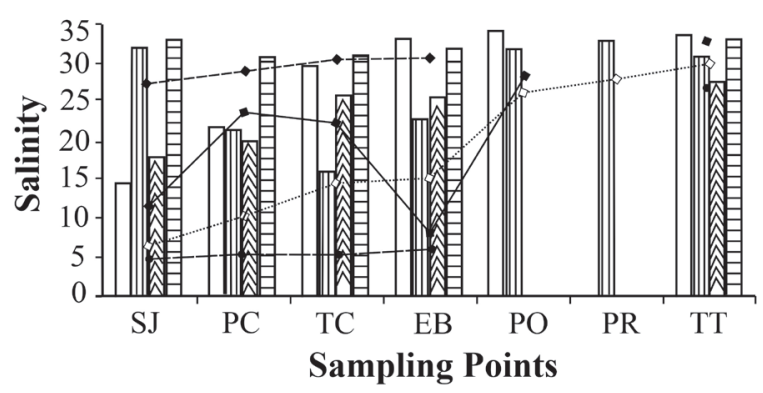

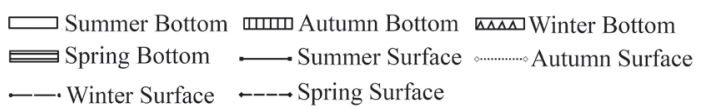

Figure 3. Mean values of salinities on the surface and the bottom at each sample point during 1999. Points within the estuary of the Patos Lagoon: São José do Norte (SJ), Pier Copesul (PC), Tecon (TC), Entre bóias 7 and 8 (EB). Points in the coastal region of the Patos Lagoon: Ponta dos Molhes (PO), Paralelo aos Molhes (PR) and Terminal Turístico (TT).

$\mathrm{m}^{-3}$ caught in two sites within the estuary (SR and $\mathrm{PA}$ ) and one site in the coastal region (PO). For the megalopa stage of each species caught on the bottom, the summer was significantly different $(\mathrm{p}<0.05)$ from the other seasons for $A$. cribrarius and C. sapidus (Tab. 3). For the total abundance of the megalopae of all species caught on the bottom, the summer was significantly different $(\mathrm{p}<0.05)$ from the other seasons (Tab. 3).

There was a significant difference $(p<0.05)$ in the megalopa stage of $A$. cribrarius between the surface and bottom (Tab. 3). When we analyzed all of the species together, we verified that there was a significant difference $(\mathrm{p}<0.05)$ between the surface and bottom (Tab. 3).

\section{Species composition 1999}

All zoeae collected were first stage of $C$. sapidus, and the total abundance was 419.78 ind $.100 \mathrm{~m}^{-3}$. Megalopae of all three portunid were collected and the total abundance was 179.91 ind $.100 \mathrm{~m}^{-3}$.

\section{Zoea phase}

On the surface, the total abundance of zoeae was 386.98 ind $100 \mathrm{~m}^{-3}$, and they were all caught during the summer at one site within the estuary and one site in the coastal region (Fig. 6A). For the zoeae caught on the surface, the summer was significantly different $(\mathrm{p}<0.05)$ from the other seasons (Tab. 4).

In the bottom samples, the abundance was 32.80 ind $100 \mathrm{~m}^{-3}$ for those caught in summer at one site 
Table 3. Results of Kruskall-Wallis ( $\mathrm{p}<0.05$ ) abundance of larval phase (zoea and megalopa) in each stratum (surface and bottom) in the estuary and coastal region of the Patos lagoon, southern Brazil, and among the seasons of the year (1995). Surface (Sur.); Bottom (Bot); not significant (ns); significant (\#); Summer (Su); Autumn (Au); Winter (Wi) and Spring (Sp).

\begin{tabular}{|c|c|c|c|}
\hline \multirow{2}{*}{ Species } & \multirow{2}{*}{ Phase } & Stratum & Seasons \\
\hline & & Sur $\mathrm{x}$ Bot & Su Au Wi Sp \\
\hline \multirow{6}{*}{ Arenaeus cribrarius Lamarck, 1818} & Zoea Sur. & & ns \\
\hline & Zoea Bot. & & ns \\
\hline & Total Zoea & ns & ns \\
\hline & Megalopa Sur. & & ns \\
\hline & Megalopa Bot. & & $\mathrm{Su} \# \mathrm{Au}=\mathrm{Wi}=\mathrm{Sp}$ \\
\hline & Total Megalopa & \# & $\mathrm{Su} \# \mathrm{Au}=\mathrm{Wi}=\mathrm{Sp}$ \\
\hline \multirow{6}{*}{ Callinectes sapidus Rathbun, 1896} & Zoea Sur. & & $\mathrm{ns}$ \\
\hline & Zoea Bot. & & ns \\
\hline & Total Zoea & ns & $\mathrm{Su} \# \mathrm{Au}=\mathrm{Wi}=\mathrm{Sp}$ \\
\hline & Megalopa Sur. & & ns \\
\hline & Megalopa Bot. & & $\mathrm{Su} \# \mathrm{Au}=\mathrm{Wi}=\mathrm{Sp}$ \\
\hline & Total Megalopa & ns & $\mathrm{Su} \# \mathrm{Au}=\mathrm{Wi}=\mathrm{Sp}$ \\
\hline \multirow{6}{*}{ Achelous spinicarpus Stimpson, 1871} & Zoea Sur. & & ns \\
\hline & Zoea Bot. & & ns \\
\hline & Zoea Total & ns & ns \\
\hline & Megalopa Sur. & & ns \\
\hline & Megalopa Bot. & & ns \\
\hline & Total Megalopa & ns & ns \\
\hline \multirow{6}{*}{ Portunidae Rafinesque, 1815 (all species) } & Zoea Sur. & & $\mathrm{Su} \# \mathrm{Au}=\mathrm{Wi}=\mathrm{Sp}$ \\
\hline & Zoea Bot. & & Su\#Au\#Wi=Sp \\
\hline & Total Zoea & ns & $S u=S p \# A u=W i$ \\
\hline & Megalopa Sur. & & ns \\
\hline & Megalopa Bot. & & $\mathrm{Su \# Au}=\mathrm{Wi}=\mathrm{Sp}$ \\
\hline & Total Megalopa & \# & $\mathrm{Su} \# \mathrm{Au}=\mathrm{Wi}=\mathrm{Sp}$ \\
\hline
\end{tabular}

within the estuary and one site at the coastal region (Fig. 6B). For the zoeae caught on the bottom, the summer was significantly different $(\mathrm{p}<0.05)$ than the other seasons (Tab. 4).

There were no significant differences $(p>0.05)$ between the zoeae caught on the surface and the bottom (Tab 4). Additionally, there was no significant difference $(p>0.05)$ between the surface and bottom when we analyzed all of the species together (Tab. 4).

\section{Megalopa phase}

On the surface, all of the megalopae collected were C. sapidus. The abundance was of 25.38 ind.100 $\mathrm{m}^{-3}$, and all were caught during the summer in one site within the estuary (SJ) and one site at the coastal region (PO). For the megalopa caught on the surface, there was no significant difference ( $p>0.05$ ) among the seasons (Tab. 4).

The abundance on the bottom was 154.53 ind $100 \mathrm{~m}^{-3}$ caught in three seasons of the year. In summer, the abundance was 111.83 ind.100 $\mathrm{m}^{-3}$, and they belonged to two species: $A$. cribrarius (92.82 ind.100 $\mathrm{m}^{-3}$ ), caught in only site in the coastal region (Fig. 7A), and A. spinicarpus (19.01 ind. $100 \mathrm{~m}^{-3}$ ), caught at one point in the coastal region (Fig. 7B). In autumn, the total abundance of megalopae was of 2.94 ind $100 \mathrm{~m}^{-3}$, and all belonged to $C$. sapidus, caught at one point in the coastal region (PR). During winter, no megalopae were caught. In spring, the abundance was 39.76 ind.100 $\mathrm{m}^{-3}$, and all belonged to $C$. sapidus caught at one point within the estuary (PC). For the megalopa stage of each species caught on the bottom, the summer was significantly different $(\mathrm{p}<0.05)$ from the other seasons for the megalopae of $A$. cribrarius (Tab. 4). However, for the total abundance of the megalopae of all of the species combined and caught on the bottom, there was no significant difference ( $p>0.05$ ) among the seasons (Tab. 4). Additionally, there was no significance difference between the surface and bottom (Tab. 4) for megalopae caught for both strata.

\section{Discussion}

After fertilization, the female of Callinectes sapidus returns to more saline waters in the lower estuary, where spawning usually occurs on an ebbing tide in the spring, summer and autumn (Perry and Stuck, 1981; Steele and Perry, 1990, Rodrigues and D'Incao, 2014) and behavioral adaptations during larval phases allow for the dispersion from coastal 

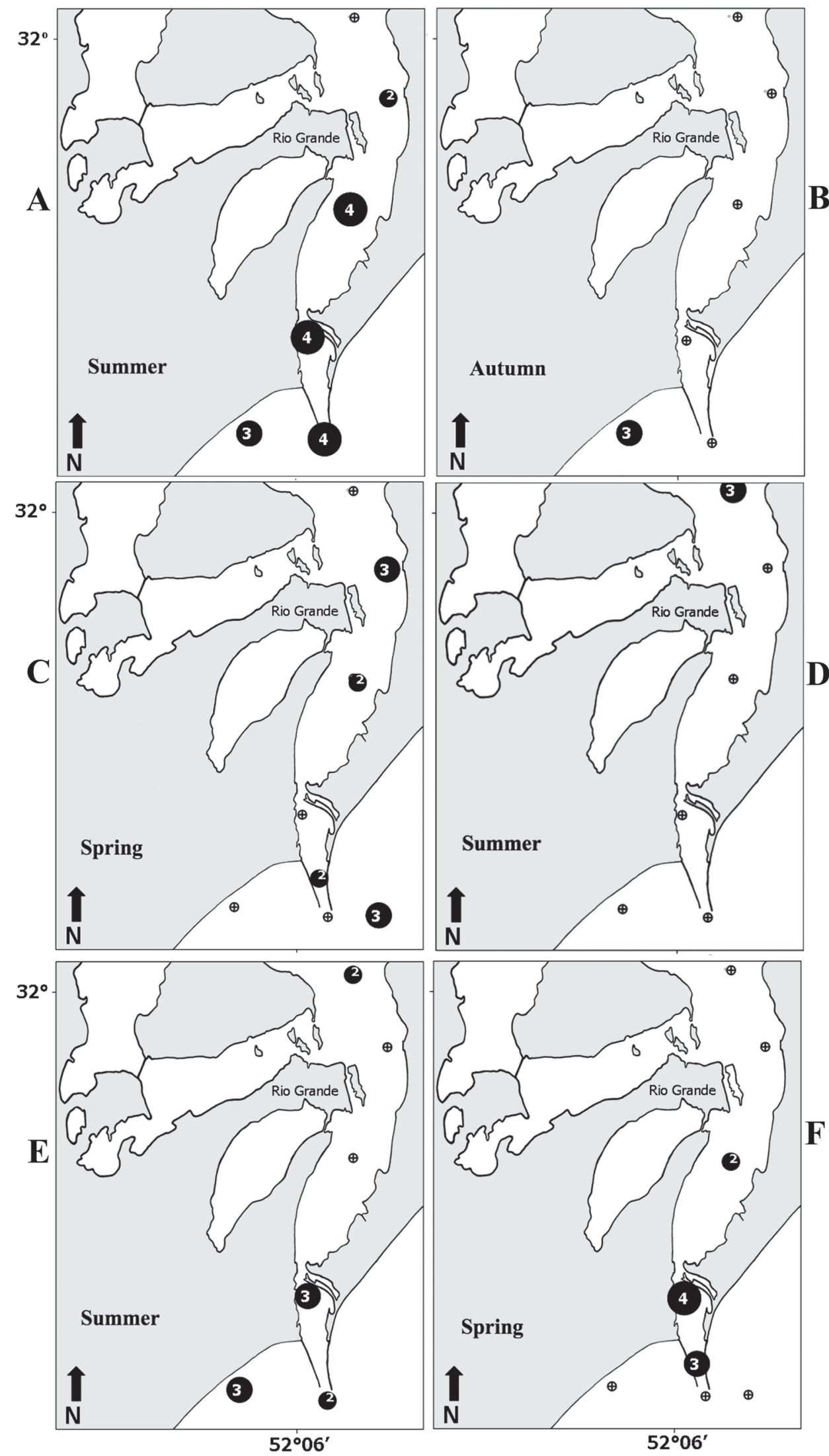

Figure 4. Spatial and seasonal distribution of zoea caught on the surface at different sampling points during 1995. A-C, Callinectes sapidus (Rathbun, 1896); D; Achelous spinicarpus Stimpson, 1871. Spatial and seasonal distribution of zoeae caught near the bottom at different sampling points during 1995. E-F, Callinectes sapidus. (0) absent; (1) extremely rare; (2) very rare; (3) rare; (4) normal; (5) abundant; (6) very abundant and (7) extremely abundant. 
Table 4. Results of Kruskall-Wallis ( $<<0.05)$ abundance of larval phase (zoea and megalopa) in each stratum (surface and bottom) and among the seasons of the year (1999). Surface (Sur); Bottom (Bot); not significant (ns); significant (\#); Summer (Su); Autumn (Au); Winter (Wi) and Spring (Sp).

\begin{tabular}{|c|c|c|c|}
\hline & & Stratum & Seasons \\
\hline Species & Phase & Sur x Bot & Su Au Wi Sp \\
\hline \multirow{6}{*}{ Arenaeus cribrarius Lamarck, 1818} & Zoea Sur. & & ns \\
\hline & Zoea Bot. & & ns \\
\hline & Total Zoea & ns & ns \\
\hline & Megalopa Sur. & & ns \\
\hline & Megalopa Bot. & & $\mathrm{Su} \# A u=W i=S p$ \\
\hline & Total Megalopa & ns & ns \\
\hline \multirow{6}{*}{ Callinectes sapidus Rathbun, 1896} & Zoea Sur. & & $\mathrm{Su} \# \mathrm{Au}=\mathrm{Wi}=\mathrm{Sp}$ \\
\hline & Zoea Bot. & & $\mathrm{Su} \# A u=W i=S p$ \\
\hline & Total Zoea & ns & $\mathrm{Su} \# \mathrm{Au}=\mathrm{Wi}=\mathrm{Sp}$ \\
\hline & Megalopa Sur. & & ns \\
\hline & Megalopa Bot. & & ns \\
\hline & Total Megalopa & ns & ns \\
\hline \multirow{6}{*}{ Achelous spinicarpus Stimpson, 1871} & Zoea Sur. & & ns \\
\hline & Zoea Bot. & & ns \\
\hline & Total Zoea & ns & ns \\
\hline & Megalopa Sur. & & ns \\
\hline & Megalopa Bot. & & ns \\
\hline & Total Megalopa & ns & ns \\
\hline \multirow{6}{*}{ Portunidae Rafinesque, 1815 (all species) } & Zoea Sur. & & $\mathrm{Su} \# \mathrm{Au}=\mathrm{Wi}=\mathrm{Sp}$ \\
\hline & Zoea Bot. & & $\mathrm{Su} \# \mathrm{Au} \# W \mathrm{i}=\mathrm{Sp}$ \\
\hline & Total Zoea & ns & $\mathrm{Su}=\mathrm{Sp} \# \mathrm{Au}=\mathrm{Wi}$ \\
\hline & Megalopa Sur. & & ns \\
\hline & Megalopa Bot. & & ns \\
\hline & Total Megalopa & ns & ns \\
\hline
\end{tabular}
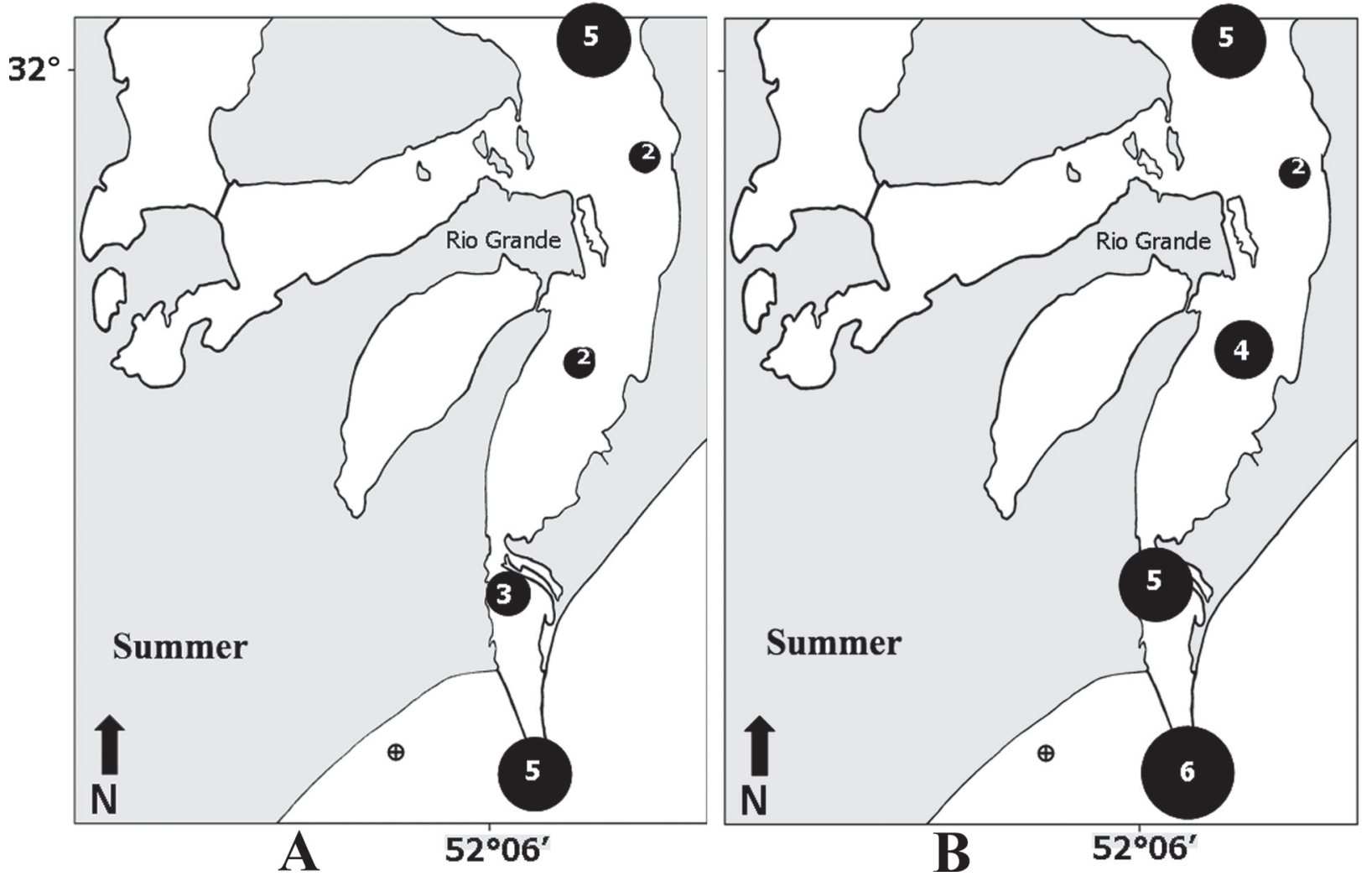

Figure 5. Spatial and seasonal distribution of megalopae caught near the bottom at different sampling points during 1995. A, Arenaeus cribrarius (Lamarck, 1818); B, Callinectes sapidus (Rathbun, 1896). (0) absent; (1) extremely rare; (2) very rare; (3) rare; (4) normal; (5) abundant; (6) very abundant and (7) extremely abundant. 

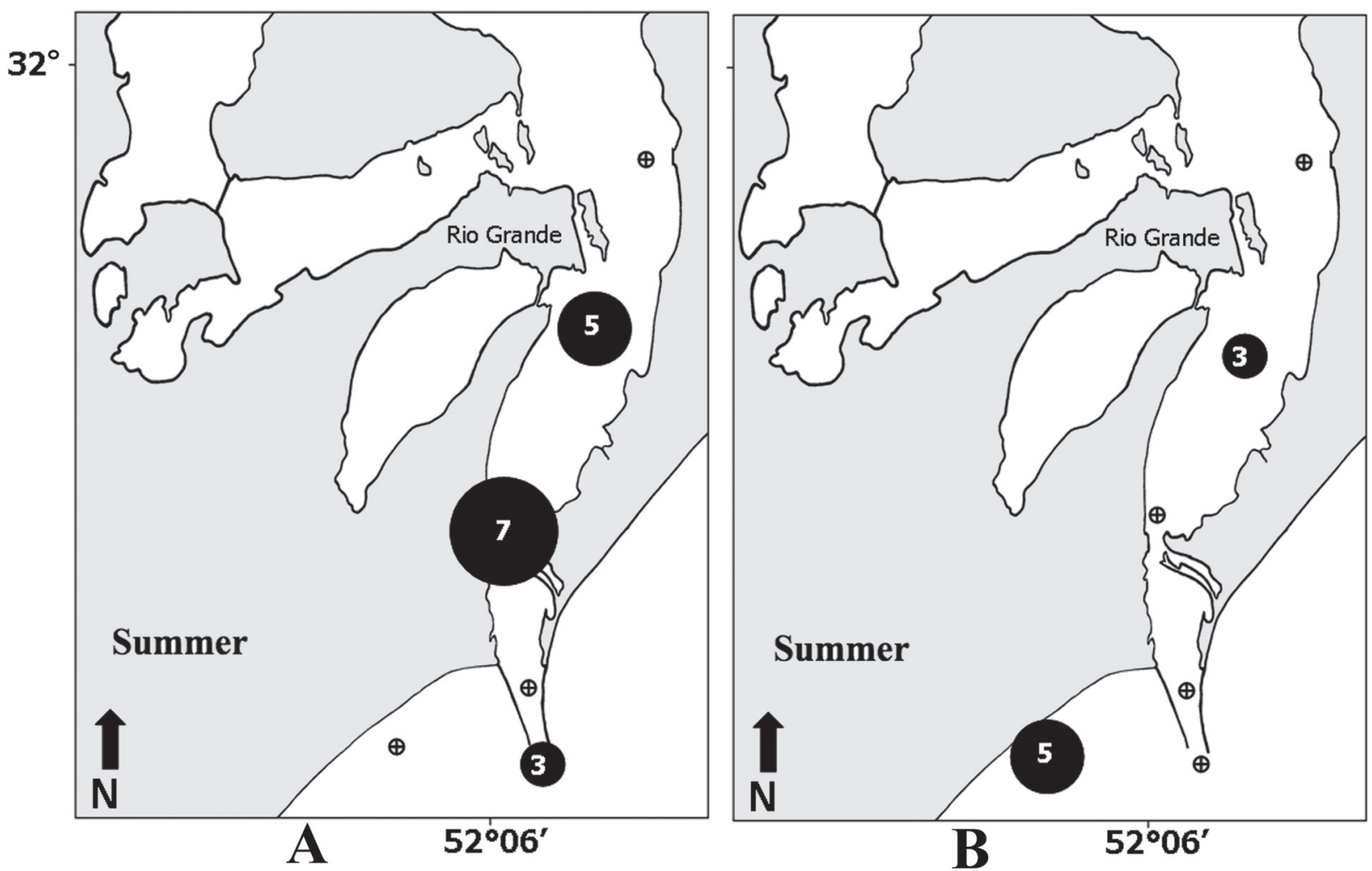

Figure 6. Spatial and seasonal distribution of Callinectes sapidus (Rathbun, 1896). A, zoea caught on the surface at different sampling points during 1999; B, zoea caught near the bottom at different sampling points during 1999. (0) absent; (1) extremely rare; (2) very rare; (3) rare; (4) normal; (5) abundant; (6) very abundant and (7) extremely abundant.
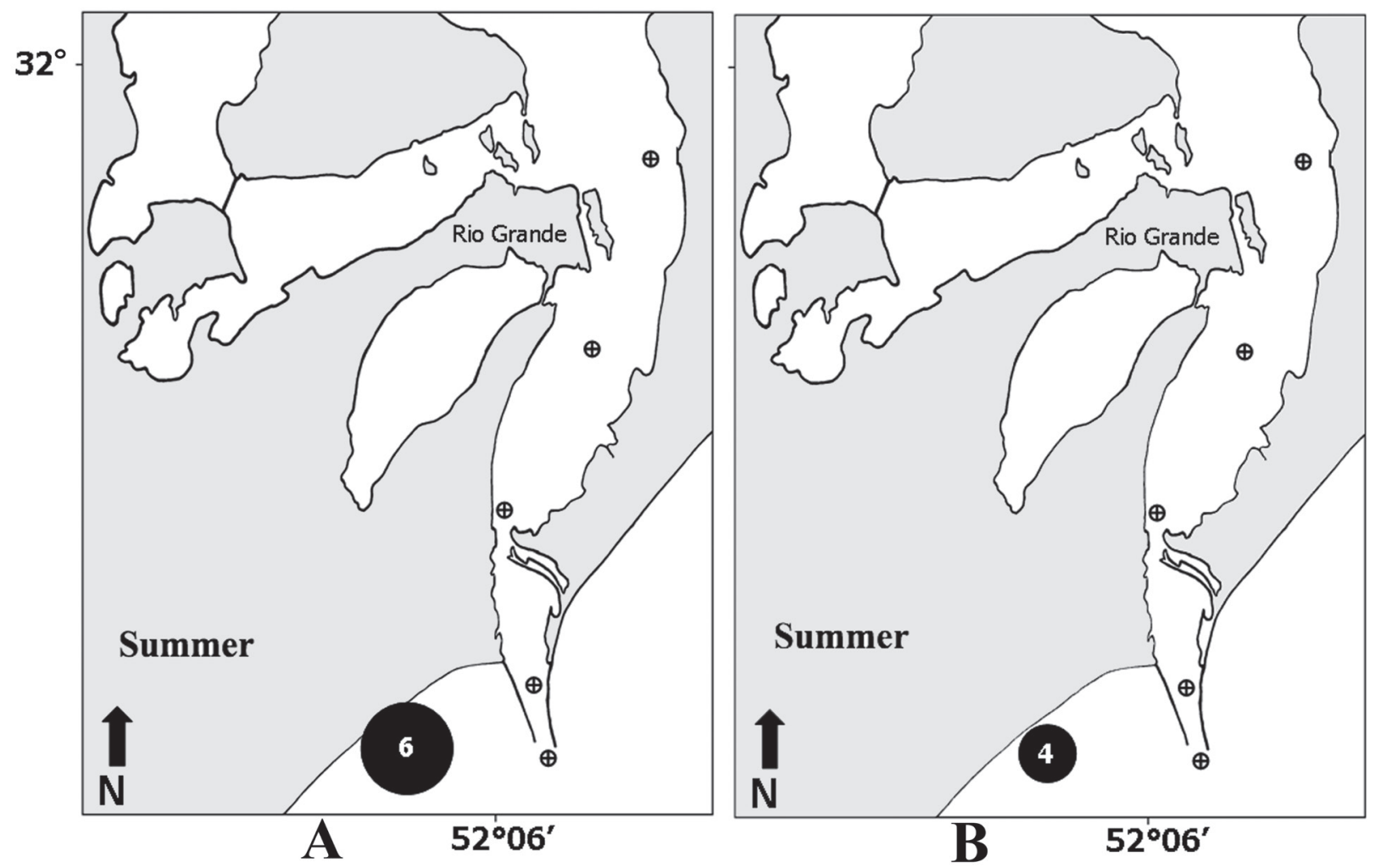

Figure 7. Spatial and seasonal distribution of megalopae caught near the bottom at different sampling points during 1999. A, Arenaeus cribrarius (Lamarck, 1818); B, Achelous spinicarpus (Stimpson, 1871). (0) absent; (1) extremely rare; (2) very rare; (3) rare; (4) normal; (5) abundant; (6) very abundant and (7) extremely abundant. 
spawning areas and recruitment back to the estuary (Sulkin et al., 1980; Sulkin and Van Heukelem, 1982). The zoeae of $C$. sapidus caught within the estuary of the Patos Lagoon on the surface were due to the spawnning that occurred inside the estuary. According to Sulkin (1984) and Epifanio et al. (1989), the first stage of zoea had negative geotaxis and high barokinesis and remained near the surface, and the zoeae were transported seaward to complete their development.

The zoeae of Achelous spinicarpus within the estuary caught in summer (mean temperature of $23.9^{\circ} \mathrm{C}$ and salinity of 18 ) were rare, because juveniles and adults inhabit only the coastal areas (Dumont and D'Incao, 2011). The bottom currents transported zoeae to the upper estuary, away from their parental habitat, where they would not complete their larval development. Bookhout and Costlow (1974) showed that zoeae of $A$. spinicarpus reared in laboratory completed the zoeal development (composed by seven stages) to megalopa phase when the temperature was above $20^{\circ} \mathrm{C}$ and salinity was greater than 30 .

The absence of Arenaeus cribrarius zoeal stages within the estuary could be explained by: a) adults living in the coastal area and b) larvae dispersed by surface currents to the continental shelf, where salinity was higher. In laboratory conditions, $A$. cribrarius larval stages needed salinity of least 25 to complete development in two months (Stuck and Truesdale, 1988).

The highest zoeal abundance of $C$. sapidus during summer was due to a greater abundance of ovigerous females with eggs in all of the developmental stages (Rodrigues et al., 2011). Zoeae caught in one site of the coastal region in early autumn were from ovigerous females from late summer. During autumn, the low salinity and temperature (the temperature average was below $18^{\circ} \mathrm{C}$ ) did not allow changes for the later stages, which was corroborated by laboratory studies performed by Costlow and Bookhout (1959), who noted that all larvae died at temperatures lower than $20^{\circ} \mathrm{C}$. By late spring, the zoeal phase has probably completed its development until the megalopa phase and would be able to settle. In the Chesapeake Bay and Delaware, USA, ovigerous females synchronized the release of zoeae with the period with higher temperatures (Provenzano et al., 1983; Epifanio et al., 1989). This fact was also observed for some planktonic species in the estuarine region of the Patos Lagoon (Montú, 1980) and in larval stages of decapod species of the coastal zone, such as the hermit crab Loxopagurus loxochelis (Moreira, 1901) (Rieger and D'Incao, 1991).

The occurrence of $A$. cribrarius megalopae during the summer in a site located within the estuary was probably due to the transport of megalopae by bottom currents. However, these megalopae would not likely change to the juvenile phase because the juveniles and adults are not found inside the estuary. On the contrary, megalopae of $A$. cribrarius and $A$. spinicarpus in the adjacent coastal region had a better chance to develop to the adult phase because the salinity was higher in that area than in the estuarine area, and it is the place where the adults are found.

The highest abundance of megalopa of $C$. sapidus was located within the estuary because the zoeae stages dispersed to the continental shelf, and according to Emilsson (1961), the southern Brazilian continental shelf of Rio Grande do Sul was covered by shallow tropical waters of the current of Brazil transporting water with temperatures above $20^{\circ} \mathrm{C}$ and a salinity of 36 . These were favorable conditions for the development of zoeal phases of C. sapidus and their return to the estuary by bottom currents during the megalopa phase.

The role that physical transport processes play in shaping the population demographics of marine species with planktonic larval stages has been well established (e.g., McConnaughey et al., 1992; Olmi, 1995; Archambault and Bourget, 1999; Hsieh et al., 2010; Daigle and Metaxas, 2011; Pan et al., 2011). Both pre and post-settlement processes are important determinants of the levels of harvestable adults. Pre-settlement processes affecting the recruitment success include both biotic (fecundity, behavior and predation) and abiotic factors (currents, winds, tides, lunar phase and water quality parameters); however, abiotic factors are thought to be the initial regulators of year class strength (Johnson and Perry, 1999). Wind stress is an especially attractive abiotic factor for inclusion 
in population predictive models because it plays a significant role in forcing surface currents over the shallow shelf regions and it is relatively easy to monitor (Johnson and Perry, 1999).

Many mechanisms were proposed for the reinvasion of megalopae into estuaries. Litlle (1990) and Johnson and Hess (1990) used a dispersal and recruitment numerical simulation and found that a 29\% average of larvae dispersal in the Chesapeake Bay would return passively by surface currents. Scheltema (1975) studied the estuaries of the South Atlantic and Mid-Atlantic Bight and found that if the megalopae became demersal on the continental shelf, they were passively transported by bottom currents to the estuary. Sulkin and Van Heukelem (1982) proposed a model for offshore recruitment based on the behavioral traits of $C$. sapidus larvae. They noted that radical behavior changes occurred in the megalopa phase, which resulted in a depth regulatory mechanism of high precision. Late-stage megalopae (near settlement) develop vertical migratory behavior that support shoreward transport. Another study suggested that this change in megalopa migratory behavior is mediated by chemical cues associated with settlement sites (Forward and Rittschof, 1994). Olmi (1995) noted that changes in megalopa behavior as they approached estuarine waters was reflected in their distributions in the water column: from a surface orientation offshore to tidally related vertical migration within the estuary. Another mechanism for reinvasion was related to wind periods toward the shore causing a positive anomaly in the water volume. King (1971) worked on the Texas coast and reported that the abundance was significantly related to the wind direction. In the estuary of the Patos Lagoon, reinvasion was probably related to wind patterns because during the low fluvial discharge (e.g., summer/autumn), onshore SE and SW winds force seawater through the inlet into the estuary and occasionally as far as $150 \mathrm{~km}$ into the lagoon (Garcia, 1998).

\section{ACKNOWLEDGMENTS}

The authors are grateful to Daniela Tannus for help to review and correct the English.

\section{REFERENCES}

Abreu, P.C. and Castello, J.P. 1998. Interaçóes entre os ambientes estuarino e marinho. p. 199-203. In: U. Seeliger; C. Odebrecht and J.P. Castello (eds), Os ecossistemas costeiro e marinho do extremo Sul do Brasil. Rio Grande, Ecoscientia.

Almeida, A.O.; Souza, G.B.G.; Boehs, G. and Bezerra, L.E.A. 2010. Shallow-water anomuran and brachyuran crabs (Crustacea: Decapoda) from southern Bahia, Brazil. Latin American Journal of Aquatic Research, 38(3): 329-376.

Archambault, P. and Bourget, E. 1999. Influence of shoreline configuration on spatial variation of meroplanktonic larvae, recruitment and diversity of benthic subtidal communities. Journal of Experimental Marine Biology and Ecology, 238(2): 161-184.

Asmus, M.L. and Tagliani, P.R.A. 1998. Consideraçóes sobre o manejo ambiental. p. 227-229. In: U. Seeliger; C. Odebrecht and J.P. Castello (eds), Os ecossistemas costeiro e marinho do extremo Sul do Brasil. Rio Grande, Ecoscientia.

Araújo, M.S.L.C.; Barreto, A.V.; Negromonte, A.O. and Schwamborn, R. 2012. Population ecology of the blue crab Callinectes danae (Crustacea: Portunidae) in a Brazilian tropical estuary. Anais da Academia Brasileira de Ciências, 84(1): 129-138.

Avila, M.G. and Branco, J.O. 1996. Aspectos bioecológicos de Arenaeus cribrarius (Lamarck) (Decapoda, Portunidae) da Praia da Barra da Lagoa, Florianópolis, Santa Catarina, Brasil. Revista Brasileira de Zoologia, 13(1): 165-174.

Baptista-Metri, C.; Pinheiro, M.A.A.; Blankensteyn, A. and Borzone, C.A. 2005. Biologia populacional e reprodutiva de Callinectes danae Smith (Crustacea, Portunidae), no Balneário Shangri-lá, Pontal do Paraná, Paraná, Brasil. Revista Brasileira de Zoologia, 22(2): 446-453.

Barros, M.P.; Silva S.D. and Pimentel, F.R. 1997. Novos registros de Brachyura (Crustacea, Decapoda) para o litoral do Estado do Pará, Brasil. Nauplius, 5(2): 153-154.

Barutot, R.A.; Vieira, R.R.R. and Rieger, P.J. 2001. Desenvolvimento juvenil de Callinectes sapidus Rathbun, 1896 (Crustacea: Decapoda: Portunidae), em laboratório, a partir de megalopas coletadas no plâncton. Comunicaçóes do Museu de Ciências e Tecnologia da PUCRS, Série Zoologia, 14(1): 23-42.

Blanton, J.; Wenner, E.; Werner, F. and Knott, D. 1995. Effects of wind-generated coastal currents on the transport of blue crab megalopa on a shallow continental shelf. Bulletin of Marine Science, 57(3): 739-752.

Bolla Júnior, E.A.; Negreiros-Fransozo, M.L. and Fransozo, A. 2008. Juvenile development of Callinectes ornatus Ordway, 1863 (Crustacea: Decapoda: Portunidae), from megalopae obtained in the neuston. Zootaxa, 1788: 1-20.

Bookhout, C.G. and Costlow Jr, J.D. 1974. Larval development of Achelous spinicarpus reared in the laboratory. Bulletin of Marine Science, 24: 20-51. 
Calazans, D. 2002. Seasonal larval composition and abundance of shrimps in the surrounding area of the Patos Lagoon mouth. Nauplius, 10(2): 111-120.

Calderon-Aguilera, L.E.; Marinone, S.G. and AragónNoriega, E.A. 2003. Influence of oceanographic processes on the early life stages of the blue shrimp (Litopenaeus stylirostris) in the upper gulf of California. Journal of Marine Systems, 39(1-2): 117-128.

Chacur, M.M. and Negreiros-Fransozo, M.L. 2001. Spatial and seasonal distributions of Callinectes danae (Decapoda, Portunidae) in Ubatuba bay, São Paulo, Brazil. Journal of Crustacean Biology, 21(2): 414-425.

Coelho, P.A. and Ramos-Porto, M. 1995. Crustáceos da região de Tamandaré, Estado de Pernambuco, Brasil. Boletim Técnico-Científico do CEPENE, 3(1): 56-80.

Costa, C.S.B.; Seeliger, U. and Kinas, P.G. 1988. The effect of wind velocity and direction on the salinity regime in the Patos Lagoon estuary. Ciência e Cultura, 40: 909-912.

Costlow Jr, J.D. and Bookhout, C.G. 1959. The larval development of Callinectes sapidus Rathbun reared in the laboratory. Biological Bulletin, 116(3): 373-396.

Daigle, R.M. and Metaxas, A. 2011. Vertical distribution of marine invertebrate larvae in response to thermal stratification in the laboratory. Journal of Experimental Marine Biology and Ecology, 409(1-2): 89-98.

Dana, J.D. 1851. On the classification of the Cancroidea. American Journal of Science and Arts, series, 212(12): 121-131.

De Haan, W. (1833-1850) Crustacea. In: P.F. von Siebold (ed) Fauna Japonica sive Descriptio Animalium, Quae in Itinere per Japoniam, Jussu et Auspiciis Superiorum, qui Summum in India Batava Imperium Tenent, Suscepto, Annis 1823-1830 Collegit, Noitis, Observationibus et Adumbrationibus Illustravit. Leiden, Lugduni-Batavorum. Pp. i-xvii, i-xxxi, ix-xvi, 1-243, Plates A-J, L-Q, 1-55, circ. Table 2.

Drake, P. and Arias, A.M. 1993. Larval feeding habits and diel rhythms of four species of marine fish in a tidal creek of Cádiz Bay (Spain). p. 153-159. In: B.T. Walther and H.J. Fyhn (eds), Physiological and Biochemical Aspects Fish Development. Bergen, University of Bergen.

Duarte, A.K.; Kinas, P.G.; Muxagata, E. and Obebrecht, C. 2014. Zooplankton biomass distributions in the Subtropical Southwestern Atlantic ocean: relationships with environmental factors and chlorophyll $a$. PanAmerican Journal of Aquatic Sciences, 9(4): 239-261.

Dumont, L.F.C and D'Incao, F. 2011. By-catch analysis of Argentinean prawn Artemesia longinaris (Decapoda: Penaeidae) in surronunding area of Patos Lagoon, southern Brazil: effects of different rainfall. Journal of the Marine Biological Association of the United Kingdom, 91(5): 10591072.

Emilsson, I. 1961. The shelf and coastal waters off southern Brazil. Boletim do Instituto Oceanográfico, 11(2): 101-112.
Epifanio, C.E. 1988. Dispersal strategies of two species of swimming crab on the continental shelf adjacent to Delaware Bay. Marine Ecology Progress Series, 49: 243-248.

Epifanio, C.E. 1995. Transport of the blue crab (Callinectes sapidus) larvae in the waters off Mid-Atlantics states. Bulletin of Marine Science, 57(3): 713-725.

Epifanio, C.E.; Masse, A.K. and Garvine, R.W. 1989. Transport of blue crab larvae by surface currents off Delaware Bay. Marine Ecology Progress Series, 54: 35-41.

Forward Jr, R.B. and Rittschof, D. 1994. Photoresponse of crab megalopae in offshore and estuarine water: implications for transport. Journal of Experimental Marine Biology and Ecology, 182(2): 183-192.

Garcia, A.M.; Vieira, J.P. and Winemiller, K.O. 2001. Dynamics of the shallow-water fish assemblage of the Patos Lagoon estuary (Brazil) during cold and warm ENSO episodes. Journal of Fish Biology, 59(5): 1218-1238.

Garcia, C.A.E. 1998. Características Hidrográficas: Fatores forçantes da circulação na Lagoa e no Estuário. p. 18-21. In: U. Seeliger; C. Odebrecht and J.P. Castello (eds), Os ecossistemas costeiro e marinho do extremo Sul do Brasil. Rio Grande, Ecoscientia.

Goodrich, D.M.; van-Montfrans, J. and Orth, R.J. 1989. Blue crab megalopal influx to Chesapeake Bay: Evidence for wind-driven mechanism. Estuarine, Coastal and Shelf Science, 29(3): 247-260.

Hsieh, H.-L.; Fan, L.-F.; Chen, C.-P.; Wu, J.-T. and Liu, W.C. 2010. Effects of semidiurnal tidal circulation on the distribution of holo- and meroplankton in a subtropical estuary. Journal of Plankton Research, 32(6): 829-841.

Johnson, D.F. and Hess, K.W. 1990. Numerical simulations of blue crab larval dispersal and recruitment. Bulletin of Marine Science, 46(1): 195-213.

Johnson, D.R.; Hester, B.S. and McConaugha, J.R. 1984. Studies of a wind mechanism influencing the recruitment of blue crabs in the middle Atlantic Bight. Continental Shelf Research, 3(4): 425-437.

Johnson, D.R. and Perry, H.M. 1999. The blue crab larval dispersion and retention in the Mississippi bight. Bulletin of Marine Science, 65(1): 129-149.

King III, B.D. 1971. Study of migratory of patterns of fish and shellfish through a natural pass. Texas Parks Wildlife Dept.. Department of Technology Services, 9: 1-54.

Kjerfe, B. 1986. Comparative oceanography of coastal lagoons. p. 63-81. In: D.A. Wolfe (ed.), Estuarine variability. New York, Academic Press.

Lamarck, J.B.P.A. de 1818. Histoire naturelle des animaux sans vertèbres, présentant les caractères généraux et particuliers de ces animaux, leur distribution, leurs classes, leurs familles, leurs genres et la citation des principales espèces qui s'y rapportent; précédé d'une introduction offrant la détermination des caractères essentiels de l'animal, sa distinction du végétal et des autres corps naturels, enfin l'exposition des principes fondamentaux de la zoologie. Tome 5, Deuxième édition. Paris, 1-612p. 
Linnaeus, C. 1758. Systema Naturae per Regna Tria Naturae, Secundum Classes, Ordines, Genera, Species, cum Characteribeus, Differentiis, Synonymis, Locis. Edition 10, 1. Holmiae, Laurentii Salvii. i-iii, 1-824p.

Little, K.T. 1990. Mechanism for the reivasion of the Atlantic blue crab, Callinectes sapidus (Rathbun) into the Delaware estuary. Bulletin of Marine Science, 46: 235-247.

Lochmann, S.E.; Darnell, R.M. and McEachran, J.D. 1995. Temporal and vertical distribution of crab larvae in a tidal pass. Estuaries, 18(1): 255-263.

Mantelatto, F.L.M. and Christofoletti, R.A. 2001. Natural feeding activity of the crab Callinectes ornatus (Portunidae) in Ubatuba Bay (São Paulo, Brazil): influence of season, sex size and molt stage. Marine Biology, 138: 585-594.

Mantelatto, F.L.M.; Christofoletti, R.A. and Camargo, P.B. 2002. A food source analysis for the swimming crab Callinectes ornatus (Portunidae) in Ubatuba Bay (Brazil), using carbon isotopes. Nauplius, 10(1): 61-66.

Mantelatto, F.L.M. and Fransozo, A. 1996. Size at sexual maturity in Callinectes ornatus (Brachyura, Portunidae) from the Ubatuba region (SP), Brazil. Nauplius, 4: 29-38.

Mantelatto, F.L.M. and Fransozo, A. 1997. Fecundity of the crab Callinectes ornatus Ordway, 1863 (Decapoda, Brachyura, Portunidae) from the Ubatuba region, São Paulo, Brazil. Crustaceana, 70(2): 214-226.

Mantelatto, F.L.M. and Fransozo, A. 1999a. Reproductive biology and moulting cycle of the crab Callinectes ornatus (Decapoda, Portunidae) from the Ubatuba region, São Paulo, Brazil. Crustaceana, 72(1): 63-76.

Mantelatto, F.L.M. and Fransozo, A. 1999b. Population biology of Callinectes ornatus Ordway, 1863 (Decapoda, Portunidae) from Ubatuba (SP), Brazil. Scientia Marina, 63(2): 157-163.

Mantelatto, F.L.M. and Martinelli, J.M. 1999. Carapace width-weight relationships of Callinectes ornatus (Brachyura, Portunidae) from Ubatuba Bay, Brazil. Iheringia, Série Zoologia, 87: 111-116.

Mantelatto, F.L.M.; Robles, R.; Schubart, C.D. and Felder, D.L. 2009. Molecular phylogeny of the genus Cronius Stimpson, 1860, with reassignment of $C$. tumidulus and several American species of Achelous to the genus Achelous De Haan, 1833 (Brachyura: Portunidae). p. 551-565. In: J.W. Martin; K.A. Crandall and D.L. Felder (eds), Decapod Crustacean Phylogenetics. Crustacean Issues, Vol. 18. Boca Raton/London/New York, CRC Press/ Taylor \& Francis Group.

McConaugha, J.R. 1988. Export and reinvasions of larvae as regulators of estuarine decapod populations. American Fisheries Society Symposium, 3: 90-103.

McConaugha, J.R.; Johnson, D.F.; Provenzano, A.J. and Maris, R.C. 1983. Seasonal distribution of larvae of Callinectes sapidus (Crustacea: Decapoda) in the waters adjacent to Chesapeake bay. Journal of Crustacean Biology, 3(4): 582-591.
McConnaughey, R.A.; Armstrong, D.A.; Hickey, B.H. and Gunderson, D.R. 1992. Juvenile Dungeness crab (Cancer magister) recruitment variability and oceanic transport during the pelagic larval phase. Canadian Journal of Fisheries Aquatic Sciences, 49(10): 2028-2044.

Montú, M. 1980. Zooplâncton do estuário da Lagoa dos Patos. I - Estrutura e variaçóes temporais e espaciais da comunidade. Atlântica, 4: 53-72.

Moreira, C. 1901. Contribuiçôes para o conhecimento da fauna Brazileira: Crustáceos do Brazil. Archivos do Museu Nacional do Rio De Janeiro 11: 1-151.

Muelbert, J.H. and Weiss, G. 1991. Abundance and distribution of fish larvae in the channel area of the Patos Lagoon estuary, Brazil. National Oceanic and Atmospheric Administration Technical Report, National Marine Fisheries Service, 95:43-54.

Negreiros-Fransozo, M.L.; Mantelatto, F.L.M. and Fransozo, A. 1999. Population biology of Callinectes ornatus Ordway, 1863 (Decapoda, Portunide) from Ubatuba (SP), Brazil. Scientia Marina, 63(2):157-163.

Negreiros-Fransozo, M.L.; Meyers, N.; Fransozo, V. and Victors, S.T. 2007. The megalopa stage of Achelous spinimanus Latreille, 1819 and Achelous gibbesii (Stimpson, 1859) (Decapoda, Brachyura, Portunidae) from the southeastern Atlantic coast of the United States. Zootaxa, 1638: 21-37.

Nichols, J.H. and Thompson, B.M. 1988. Quantitative sampling of crustacean larvae and its use in stock size estimation of commercially exploited species. Symposia of the Zoological Society of London, 59: 157-175.

Oliveira, A.; Pinto, T K.; Santos, D.P.D. and D’Incao, F. 2006. Dieta natural do siri-azul Callinectes sapidus (Decapoda, Portunidae) na regiáo estuarina da Lagoa dos Patos, Rio Grande, Rio Grande do Sul, Brasil. Iheringia, Série Zoologia, 96(3): 305-313.

Olmi, E.J. 1995. Ingress of blue crab megalopae in the York River, Virginia, 1987-1989. Bulletin of Marine Science, 57(3): 753-780.

Pan, M.; Pierce, G.J.; Cunningham, C.O. and Hay, S.J. 2011. Seasonal and interannual variation of decapod larval abundance from two coastal locations in Scotland, UK. Journal of the Marine Biological Association of the United Kingdom, 91(7): 1-9.

Pardal-Souza, A.L. and Pinheiro, M.A.A. 2013. Relative growth and reproduction in Achelous spinicarpus (Crustacea: Portunidae) on the south-eastern continental shelf of Brazil. Journal of the Marine Biological Association of the United Kingdom, 93(3): 667-674.

Perry, H.M. and Stuck, K.C. 1981. The life history of the blue crab in Mississippi with notes on larval distribution. p. 17-22. In: H.M. Perry and W.A. Van Engel (eds), Proceedings of the Blue Crab Colloquium, Number 7. Biloxi, Mississippi, Gulf States Marine Fisheries Commission. 
Pinheiro, M.A.A. and Fransozo, A. 2002. Reproduction of the speckled swimming crab Arenaeus cribrarius (Brachyura: Portunidae) on the Brazilian coast near 23030'S. Journal of Crustacean Biology, 22(2): 416-428.

Provenzano Jr, A.J.; McConaugha, J.R.; Phillips, K.B.; Johnson, D.F. and Clark J. 1983. Vertical distribution of first stage larvae of the blue crab, Callinectes sapidus, at the mouth of Chesapeake Bay. Estuarine, Coastal and Shelf Science, 16(5): 489-499.

Rafinesque, C.S. 1815. Analyse de la Nature, ou Tableau de l'Univers et des Corps Organisés. Palermo: L'Imprimerie de Jean Barravecchia. 224 p.

Rathbun, M.J. 1896. The genus Callinectes. Proceedings of the United States National Museum, 18(1070): 349-375.

Rieger, P.J. and D’Incao, F. 1991. Distribuição das larvas de Loxopagurus loxochelis (Decapoda. Diogenidae) na região adjacente a barra de Rio Grande, RS. Neritica, 6(1-2): 93-106.

Rodrigues, M.A. and D'Incao, F. 2014. Biologia reprodutiva do siri-azul Callinectes sapidus no estuário da Lagoa dos Patos, RS, Brasil. Boletim do Instituto de Pesca, 40(2): 223-236.

Rodrigues, M.A.; Heberle, M.F. and D'Incao F. 2011. Fecundity variation and abundance of female blue crabs Callinectes sapidus Rathbun, 1896 (Decapoda, Brachyura, Portunidae) in the Patos Lgoon estuary, RS, Brazil. Atlântica, 33(2): 141-148.

Sankarankutty, C.; Hong, S.Y. and Kim, K.W. 1999. Description of laboratory reared first zoea of Callinectes danae Smith (Crustacea, Decapoda, Portunidae). Revista Brasileira de Zoologia, 16(2): 45-49.

Scheltema, R.S. 1975. Relationship of larval dispersal, gene flow and natural selection to geographic variation of benthic invertebrates in estuaries and along coastal regions. p. 372-391. In: L.E Cronin (ed.), Estuarine Research, Vol. 1, Chemistry, Biology and the Estuarine System. New York, Academic Press.

Seeliger, U.; Odebrecht, C. and Castello, J.P. 1998. Os ecossistemas costeiro e marinho do extremo Sul do Brasil. Rio Grande, Ecoscientia, 326p.

Steele, P. and Perry, H.M. 1990. The blue crab fishery of the Gulf of Mexico United States: A regional management plan. Publ. 21, Ocean Springs, Mississippi, Gulf States Marine Fisheries Commission.

Stimpson, W. 1860. Notes on North American Crustacea, in the Museum of the Smithsonian Institution, No. II. Annals of the Lyceum of Natural History of New York, 7: 177-246, Plates II and V.

Stimpson, W. 1871. Preliminary report on the Crustacea dredged in the Gulf Stream in the Straits of Florida by L.F. de Pourtales, Assist. U. S. Coast Survey. Part I. Brachyura. Bulletin of the Museum of Comparative Zoölogy at Harvard College, 2: 109-160.

Stuck, K.C. and Truesdale, F.M. 1988. Larval development of the speckled swimming crab, Arenaeus cribrarius (Decapoda: Brachyura: Portunidae) reared in the laboratory. Bulletin of Marine Science, 42(1): 101-132.

Sulkin, S.D. 1984. Behavioral basis of depth regulation in the larvae of brachyuran crabs. Marine Ecology, 15: 181-205.

Sulkin, S.D. and Van Heukelem, W. 1982. Larval recruitment in the crab, Callinectes sapidus Rathbun: an amendment to the concept of larval retention in estuaries. p. 459-476. In: V.S. Kennedy (ed), Estuarine Comparisons. New York, Academic Press, Inc..

Sulkin, S.D.; Van Heukelem, W.; Kelly, P.V. and Van Heukelem, L. 1980. The behavioral basis of larval recruitment in the crab Callinectes sapidus Rathbun: a laboratory investigation of ontogenetic changes in geotaxis and barokinesis. Biological Bulletin, 59(2): 402-417.

Teixeira, R.L. and Sá, H.S. 1998. Abundância de macrocrustáceos decápodas nas áreas rasas do complexo Lagunar Mundaú/Manguaba, AL. Revista Brasileira de Biologia, 58(3): 393-404.

Vieira, R.R.R. and Calazans D. 2010. Chave ilustrada para identificação das zoés de Brachyura do estuário da Lagoa dos Patos (RS) e região costeira adjacente. Biota Neotropica, 10(3): 431-437.

Weber, L.I.; Puchnick, A.; Lamego, J.P. and Levy, J.A. 2003. Genetic relationships among the most common swimming crabs of southern Brazil. Journal of Crustacean Biology, 23(1): 201-211.

Zar, J. J. 1999. Biostatistical analysis. New Jersey, Prentice Hall. 